IJTC

Ilomata International Journal of Tax \& Accounting

P-ISSN: 2714-9838; E-ISSN: 2714-9846

Vol. 1 No. 2 March 2020

https://www.ilomata.org/index.php/iitc

The Effect of Accounting Information Systems (AIS), Leadership Style, Motivation, and Working the environment on the Employee's Performance at Badan Keuangan Daerah (BKUD) Regency Semarang

\author{
Dyah Pramesti Nur Azizah, Mohamad Hasanudin*, Toni Hartono \\ Accounting Division of Politeknik Negeri Semarang \\ mohammad.hasanudin@polines.ac.id
}

Submitted : Jan 3th 2020 Revised : Feb $18^{\text {th }} 2020$ Published : March $30^{\text {th }} 2020$

\begin{abstract}
This study aims to determine whether the Accounting Information System, Leadership Style, Motivation, and Work Environment together have a significant effect on the Performance of Employees at Badan Keuangan Daerah (BKUD) Kabupaten Semarang. Samples that met the criteria in this study were 65 . The analysis used is multiple regression analysis preceded by a classic assumption test consisting of the normality test, multicollinearity test, and heteroscedasticity test. While hypothesis testing is done using the F test and t-test. The results of data analysis or regression results indicate that partially the Accounting Information System, Leadership Style, Motivation, and Work Environment influence employee performance. Simultaneously the Accounting Information System, Leadership Style, Motivation, and Work Environment contributed $84.6 \%$ of the effect on the level of the dependent variable, namely employee performance.
\end{abstract}

Keywords: Accounting Information Systems (AIS), Leadership Style, Motivation, Working Environment, Employee's Performance.

\title{
INTRODUCTION
}

Employee's performance is one of the important factors for the success of an organization. Employees are one of the very valuable organizational assets that must be managed properly by the organization to provide an optimal contribution. Employees are always involved in every process and operational management within the organization. Each organization will always strive to improve the performance of employees in the hope of what the company goals can be achieved. The survival of an organization is influenced by human resources quality and quantity to achieve organizational goals quickly and be able to compete globally(Rulandari et al., 2018; Sofyan, 2016).

Accounting Information Systems (AIS) is good for the organization because it can help the process of operation and information more effectively and efficiently. Not only to save costs and time, but Accounting Information Systems (AIS) also has an impact on the company's activities after the decision-making in an organization and used by an external party organization in business activities. The successful development of qualified human resources comes from the influence of a leader. Leaders as a source of human resource managers are required to have a style of leadership in working together to reduce the possibility of conflicts that can occur in the 
The Effect of Accounting Information Systems (AIS), Leadership Style, Motivation, and Working Environment on The Employee's Performance at Badan Keuangan Daerah (BKUD) Semarang Regency Azizah, Hasanudin, and Hartono working group to achieve an organizational goal or company. The success or failure of an organization is usually perceived as a success or a failure of leadership.

Employee's performance can also be influenced by motivation. Motivation can be interpreted simply as a condition or action that encourages a person to be able to do a job as much as possible to produce a good performance. The influence of motivation is also very important to cultivate the discipline and responsibility of employees in the work. Another factor to be considered by the company is working environment. Working environment better if it could have a positive influence on employee's performance. The working environment can also foster employee morale and affect the results of the employees. Based on the analysis of SWOT method carried out by Badan Keuangan Daerah (BKUD) Kabupaten Semarang to determine the condition of the strategic environmental organizations, there are some weaknesses and threats, as follows:

Weaknesses:

1. As a newly formed regional organization.

2. The number of financial technical rules that are interpretative.

3. Comunications on line system in the financial administration system with Satuan Kerja Perangkat Daerah (SKPD) has not been created yet in the area of Semarang Distric Goverment.

4. Lack of accounting.

5. The socialization to taxpayers has not been optimal yet.

Threats:

1. Lack of understanding of the budget users on performance- based budget.

2. Administration of finances in SKPD has not been orderly yet.

3. Accounting implementation in SKPD has not been optimal yet.

4. Users time allocation are less effective

Source: Profile of Badan Keuangan Daerah (BKUD) Kabupaten Semarang (2018).

Based on the formulation of the problem, this study has the following objectives:

1. To determine and analyze the significance affect of Accounting Information System (AIS) partially on the Employee's Performance.

2. To determine and analyze the significance affect of the Leadership Style partially on the Employee's Performance.

3. To determine and analyze the significance affect of Motivation partially on Employee's Performance.

4. To determine and analyze the significance affect of Working Environment partially on Employee's Performance.

To determine and analyze the significance affect of Accounting Information System (AIS), Leadership Style, Motivation, and Working Environment simultaneously on Employee's Performance.

\section{Accounting Information Systems (AIS)}

Krismiaji (2010) states accounting information systems is a system that processes data and transactions in order to generate information useful for planning, controlling, and operating a business.

According to Susanto (2013:22) in Melasari (2017:3), there are three functions of accounting information system. The third function of accounting information systems can be explained as 
The Effect of Accounting Information Systems (AIS), Leadership Style, Motivation, and Working Environment on The Employee's Performance at Badan Keuangan Daerah (BKUD) Semarang Regency Azizah, Hasanudin, and Hartono follows:

1. Supporting Company Daily Activities

2. Supporting the Decisions Making Process

3. The company helps business Fulfilling its responsibilities to External Parties There are five (5) the role of accounting information systems (AIS) according to Susanto (2013) in Melasari (2017), namely:

1. Collecting and entering data into Accounting Information Systems

2. The transaction data processing

3. Storing data for the purpose of future

4. Giving users or decision makers (management) information they need

5. Controls all the processes that occur

\section{Leadership Styles}

Hasibuan (2016) states that leadership style is a way a leader influences the behavior of subordinates, in order to work productively to achieve organizational goals. The leadership style according to Hasibuan opinion (2016) leadership style is divided into three parts, namely:

1. Authoritarian leadership Authoritarian Leadership is if the power or authority, the absolute majority remain in the leadership or the leadership if it adopts a centralized authority. Decision-making and policies defined only by the leaders, subordinates are not included to provide advice, ideas, and other considerations in the decisions making process. Orientation leadership is focused only to increase employee productivity with little regard for the feelings and welfare of subordinates.

2. Participative leadership

Participative leadership is one where the leadership is done by persuasion, creating a harmonious cooperation, foster loyalty and participation followers. Leaders motivate subordinates to feel co-owns the company. Subordinates should participate to give advice, ideas, and other considerations in the decision-making process. Leaders with a participative style will encourage their subordinates make decisions. Thus, the leadership will always nurture subordinates to accept greater responsibility.

3. Delegative leadership Delegative leadership when a leader delegate authority to subordinates rather incomplete. Thus, subordinates may take decisions and wisdom with free or free to do the job. Leaders do not care how subordinates make decisions and do his job is left entirely to subordinates.

\section{Motivation}

According to Hasibuan (2016) motivation is the cause, distributes, and supports human behavior so that they work hard and enthusiastically to achieve optimal results. Sutrisno (2017) motivation as a psychological process in a person will be affected by several factors. Factors these factors are:

1. Internal factors
a. The desire to live
b. The desire to be able to have
c. The desire to gain an appreciation
d. The desire for recognition
e. The desire for power 
The Effect of Accounting Information Systems (AIS), Leadership Style, Motivation, and Working Environment on The Employee's Performance at Badan Keuangan Daerah (BKUD) Semarang Regency Azizah, Hasanudin, and Hartono

2. External factors
a. Working conditions
b. Adequate compensation
c. Good supervision
d. Employment security
e. Status and responsibility
f. Flexible regulation

\section{Working Environment}

Sedarmayanti (2011) dalam Furthermore, according to Sedarmayati (2011) in Qomariah (2016) the work environment is the entire machine tools and materials at hand, the surrounding environment in which a person is working, working methods, as well as the arrangement works both as individuals and as a group. According Sedarmayanti (2011) in Inbar et al (2018) outlines, the type of work environment is divided into two, namely:

1. Physical Work Environment Physical work environment are all located around the workplace that may affect the employees either directly or indirectly. Physical work environment can be divided into two categories, namely:

a. Environment is directly related to the employees as the work center, chairs, tables, and so on.

b. Environmental intermediary or the general environment can also be called a work environment that affect the human condition, such as temperature, humidity, air circulation, lighting, noise, mechanical vibration, odor, color, etc.

2. Non Physical Work Environment

Non-physical work environment are all circumstances that occur relating to the employment relationship, either with superiors or with fellow colleagues or relations with subordinates.

\section{Employee Performance}

According to Moeheriono (2014) employee performance is an overview of the level of achievement of the implementation of a program of activities or policies in realizing the goals, objectives, vision and mission of the organization that poured through the strategic planning of an organization. Dimensions and Performance Indicators Employees (Mathis, 2006):

1. Hard Skill
a. Quantity
b. Quality

2. Soft Skill
a. Punctuality
b. Presence
c. Interoperability

\section{METHOD}

Population is a generalization region consisting of the objects/subjects that have certain qualities and characteristics defined by the researchers to learn and then drawn conclusions (Sugiyono, 2016). The population in this study were all employees who worked at the Badan Keuangan Daerah (BKUD) Kabupaten Semarang by the total number of 78 people. 
The Effect of Accounting Information Systems (AIS), Leadership Style, Motivation, and Working Environment on The Employee's Performance at Badan Keuangan Daerah (BKUD) Semarang Regency Azizah, Hasanudin, and Hartono

According Sugiyono (2016), research variable is an attribute or trait or value of a person, object or activity which may have certain variations defined by the researchers to learn and then drawn conclusions. The independent variable is the variable that affects or is the cause of the change or the emergence of the dependent variable. (Sugiyono, 2016). In this case the independent variables that will be relevant to the issues to be studied are Accounting Information Systems (AIS) (X1), Leadership Style (X2), Motivation (X3), and Working Environment (X4). The dependent variable is the variable that is affected or which become due, because of the variable free (Sugiyono, 2016). In this study, the dependent variable is Employee's Performance (Y). In this study, the measurement scale used is Likert scale. Likert scale is a tool used to measure attitudes, opinions, and the perception of a person or group of social phenomena (Sugiyono, 2016).

\section{RESULT AND DISCUSSION}

\section{The Effect of Accounting Information Systems on Performance}

The results showed that the hypothesis said there was a positive influence between Accounting Information System Performance Against was proven. This is evidenced by the significant value of less than $0.05(0.016<0.05)$. Accounting information system is an information system in an organization that is responsible for presenting the accounting information for the interested parties both within the organization and outside the organization obtained through the process of data collection and processing of transactions. Accounting information systems used by the wearer is important decision-making process in an organization. According to Parjanti (2014) accounting information systems affect the performance of employees and it is significant. The better the information systems in an organization also increases the performance of employees in the organization.

\section{The Effect of Leadership Style on Performance}

The results showed that the hypothesis that said there was a positive influence between Leadership Style against performance was proven. This is evidenced by the significant value of less than $0.05(0.000<0.05)$. The leadership style is one of the ways used by a leader in influencing, directing, and controlling employee behavior to achieve the purpose of the organization or group. Parjanti (2014) states leadership has significant influence on employee performance. The better the leadership style applied by a manager in leading his team the better the performance of employees in the organization.

\section{The Effect of Motivation on Performance}

The results showed that the hypothesis that said there was a positive influence between Motivation on performance was proven. This is evidenced by the significant value of less than $0.05(0.000<0.05)$. Motivation can be interpreted simply as a condition or action that encourages a person to be able to do a job as much as possible to produce a good performance. The influence of motivation is also very important to cultivate the discipline and responsibility of employees in the work. By having employees who have a high motivation to work, the employee can perform their duties optimally. According to Lestari (2017) motivation has positive and significant effect on the performance of employees, this means that an increase in motivation will improve the performance of employees in the company. 
The Effect of Accounting Information Systems (AIS), Leadership Style, Motivation, and Working Environment on The Employee's Performance at Badan Keuangan Daerah (BKUD) Semarang Regency Azizah, Hasanudin, and Hartono

\section{The Effect of Working Environment on Performance}

The results showed that the hypothesis that said there was a positive influence between work environment with performance has been proven. This is evidenced by the significant value of less than $0.05(0.000<0.05)$. The working environment is the social, psychological, and physical within the company that affect the workers in their duties. Human life can not be separated from the various circumstances surrounding environment, between man and the environment there is a very close relationship. In this case, people will always try to adapt to different circumstances surrounding environment. Similarly, when doing the job, the employee as a human being can not be separated from the various circumstances surrounding their place of work, the work environment. According Fachreza, Musnadi, and Majid (2018) working environment has significant and positive effect on employee's performance.

\section{Effect of Accounting Information Systems, Leadership Style, Motivation and Working Environment on Employee's Performance}

The results showed that the hypothesis that said the accounting information systems, leadership style, motivation and work environment simultaneously affected the performance is acceptable with a significance value of 0.000 . Accounting information systems relevant to the field of work will support employee performance. Similarly, the leadership style. Model or the right leadership style will be able to maximize performance results. Motivational factors and work environment can also support the performance of employees to be able to support any workload that was the obligation of the employee. Accounting Information Systems (AIS), Leadership Style, Motivation, and Working Environment have a role in improving employee performance which is an important part of the organization's activities. By using four variables, it makes it possible to measure how the performance of the organization's employees.

\section{CONCLUSION}

Results of research and discussion that has been presented based on the data research, as follows:

1. Accounting information system affect the performance of employees.

These results indicate that the better the information systems in an organization, it also increased the performance of employees in the organization.

2. Leadership style influence on employee performance.

These results indicate that the better the leadership style applied to a leader of the working group the better the performance of employees in the organization.

3. Motivation affect the performance of employees.

This means that an increase in motivation will improve the performance of employees in the company.

4. Working environment influence on employee's performance.

This means that an increase in the working environment will improve the performance of employees in the company.

5. Accountinginformation systems, leadership style, motivation and working environment simultaneously affect the performance of employees.

Referring to the limitations of the study above, the agenda of future studies, should examine the factors that affect performance such as organizational culture, work discipline and compensation.

64 | Ilomata International Journal of Tax \& Accounting 
The Effect of Accounting Information Systems (AIS), Leadership Style, Motivation, and Working Environment on The Employee's Performance at Badan Keuangan Daerah (BKUD) Semarang Regency Azizah, Hasanudin, and Hartono

Besides it is necessary to increase the number of research samples in order to obtain results that are more varied.

\section{REFERENCE}

Ghozali, I. (2018). Aplikasi Analisis Multivariate Dengan Program IBM SPSS 25.

Semarang: Badan Penerbit Universitas Diponegoro.

Hasibuan, M. S. (2016). Manajemen Sumber Daya Manusia. Jakarta: PT Bumi Aksara.

Krismiaji. (2010). Sistem Informasi Akuntansi. Yogyakarta: UPP AMP YKPN.

Mathis, J. H. (2006). Manajemen Sumber Daya Manusia. Jakarta: Salemba Empat.

Melasari, R. (2017). Pengaruh Sistem Informasi Akuntansi terhadap Kinerja Karyawan dengan Integritas Karyawan Sebagai Variabel Pemoderasi pada Perbankan di Tembilahan. Akuntansi dan Keuangan, 1-15.

Moeheriono. (2014). Pengukuran Kinerja Berbasis Kompetensi. Jakarta: Rajawali Pers.

Noor Rika Dinata Inbar, E. S. (2018). Pengaruh Lingkungan Kerja Terhadap Disiplin Kerja dan Semangat Kerja Karyawan (Studi Pada Karyawan PDAM Kota Malang). Jurnal Administrasi Bisnis (JAB), 84-92.

Qomariah, N. (2016). Pengaruh Program Kemitraan Lingkungan Kerja, dan Motivasi terhadap Kinerja Karyawan UMKM di Kecamatan. Jurnal Riset Ekonomi dan Manajemen, 145-159.

Rulandari, N., Rusli, B., Mirna, R., Nurmantu, S., \& Setiawan, M. I. (2018). Valuation of production sharing contract cost recovery vs gross split in earth oil and gas cooperation contracts in Indonesia and the aspect of public service. Journal of Physics: Conference Series, 1114(1), 12132.

Sofyan, M. (2016). Pengaruh Suku Bunga Kredit Modal Kerja, Capital Adequacy Ratio dan Loan to Deposit Ratio terhadap Kredit Modal Kerja Bank Perkreditan Rakyat (Studi Kasus Pada BPR Di Kabupaten Provinsi Jawa Timur Tahun 2010-2015). Jurnal Ekonomika, 9(2), 131137.

Sugiyono. (2013). Metodelogi Penelitian Kuantitatif, Kualitatif Dan R\&D. Bandung: Alfabeta.

Sutrisno, E. (2011). Manajemen Sumber Daya Manusia. Jakarta: Kencana. 